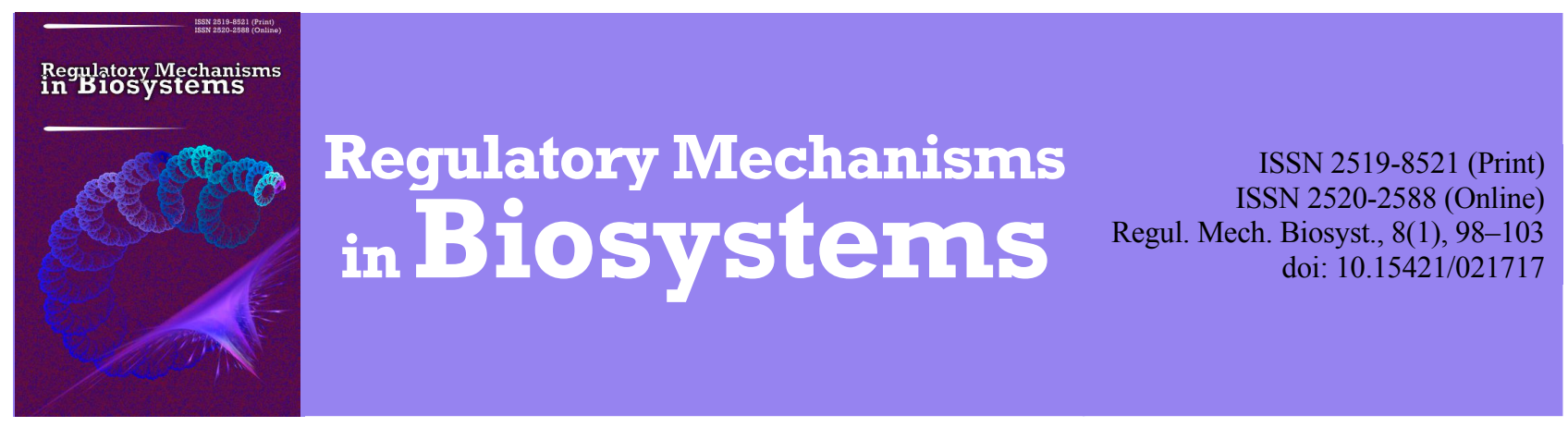

\title{
Ultrastructural changes in biofilm forms of staphylococci cultivated in a mixed culture with lactobacilli
}

\author{
G. Lavryk, O. Korniychuk, M. Tymkiv \\ Danylo Halytskyi Lviv National Medical University, Lviv, Ukraine
}

Article info

Received 19.01.2017

Received in revised form 17.02.2017

Accepted 20.02.2017

Danylo Halytskyi Lviv National Medical University, Pekarska Str., 69, Lviv,

79000, Ukraine

E-mail:lavrykgal@gmail.com

Lavryk, G., Korniychuk, O., \& Tymkiv, M. (2017). Ultrastructural changes in biofilm forms of staphylococci cultivated in a mixed culture with lactobacilli. Regulatory Mechanisms in Biosystems, 8(1), 98-103. doi: 10.15421/021717

The capacity of opportunistic bacteria for biofilm formation plays an important role in the development of chronic inflammatory processes, which are difficult to treat. To improve antimicrobial therapy methods, the influence of lactobacilli on the ultrastructure of biofilm-forming clinical strains of staphylococci when co-cultured was investigated. 5 biofilm-forming clinical strains of $S$. aureus from the skin of acne vulgaris patients $(\mathrm{n}=24)$ were isolated. Using transmission electron microscopy (TEM) the morphological changes of $S$. aureus cells in the mixed culture with standard strains of Lactobacillus plantarum 8P-A3 and clinical strains of L. fermentum $(\mathrm{n}=4)$ were studied. It was found that in 48 hours after the inoculation on the medium of samples of mixed cultures of L. plantarum 8P-A3 and $S$. aureus growth of staphylococci was not revealed. Only in some cases of mixed cultures of $L$. fermentum and biofilmforming staphylococci was growth of $S$. aureus obtained. In electron diffraction patterns of control samples of 24-hour staphylococcal monocultures and 48-hour lactobacilli monocultures, natural development of the population at the cellular level was observed. Destructive changes under the influence of lactobacilli (probiotic and clinical strains) were detected in all ultrathin sections of the cells of biofilm-forming and planktonic staphylococci. Significant destructive changes in the cell wall of the staphylococci were observed: thickening, obtaining of irregular form, detachment of the cytoplasmic membrane, the complete destruction of the peptidoglycan layer and the emergence of "shadow cells". On all electron diffraction patterns fibrillar-threadlike structures of DNA could not be observed, but in some cases mesosome-like formations were poorly contrasted. It was established that the surface S-layer of lactobacilli was expressed on a significantly larger scale in the mixed culture with staphylococci. In mixed culture of clinical strains of lactobacilli with biofilm form of $S$. aureus, staphylococcal cells could be found in a dormant state. Thanks to an experimental model of biofilm in a mixed culture, the development of destructive changes of staphylococci under the influence of the lactobacilli both on the morphological and at the population levels has been assessed. The results obtained can be used in improving the schemes of complex antimicrobial therapy of pyoinflammatory processes with the use of biological preparations, which are composed of lactobacilli, including those in the form of local application.

Keywords: biofilm; Lactobacillus; Staphylococcus aureus; transmission electron microscopy

\section{Introduction}

Staphylococci, as ubiquitous opportunistic microorganisms, colonize the skin of the mucous membranes of many human body ecosystems (nasopharynx and oropharynx, gastrointestinal tract, vagina) (Wertheim et al., 2005). The carriage of staphylococci in the human population is over 20\% (Kluytmans et al., 1997; Dall'Antonia et al., 2005). Staphylococcus aureus biofilm formation is a serious problem in nosocomial infections, and especially in the development of resistance to the majority of existing antibiotics. It should be stated that the ability to colonize and form biofilms on medical implants, catheters, endotracheal tubes, leads to the emergence of serious catheter-ventilator-associated infectious complications, sepsis (Reid, 1999; Weinstein and Darouiche, 2001; Ghannoum and O'Toole, 2004; Pal et al., 2007; Eftekhar and Mirmohamadi, 2009; Revdiwala et al., 2012, Nair et al., 2014). Furthermore, $60-65 \%$ of infections of the respiratory and urinary tract, osteomyelitis, endocarditis, cystic fibrosis, periodontitis, sores, etc. are caused by biofilm forms of bacteria (HallStoodley and Stoodley, 2009; Wang et al., 2010). S. aureus is a major cause of development of persistent, chronic pyoinflammatory infections (Otto, 2008; Hall-Stoodley and Stoodley, 2009; Gostev and Sido- renko, 2010). Biofilm microbiota, being in a symbiotic relationship with the macroorganism, create a powerful biological barrier, which prevents colonization of the epithelium by pathogenic microorganisms and ensures the preservation of its own microflora in natural human biotopes (Shyrobokov et al., 2009; He et al., 2011). It was found that human commensal microorganisms, being a part of the skin microbiocenoses, intestines, mucous, form complex interspecific communities (Hall-Stoodley and Stoodley, 2009; Harriott and Noverr, 2009). These formations are social systems characterized by certain co-operation and functional specialization, controlled by the QS-system (quorum sensing). Global regulation ensures the formation of biofilm, as well as increased bacterial adhesion, the beginning of the synthesis of the factors associated with the antagonistic activity for representatives of indigenous microflora and the manifestation of the pathogenicity for opportunistic microflora (MacFarlane, 2008; Bondarenko, 2011).

Lactobacilli are essential symbionts and members of various human body ecosystems. Anti-staphylococcal activity of lactobacilli strains is carried out by the production of nonspecific antimicrobial metabolites, such as organic acids including lactic, acetic, propionic and butyric, hydrogen peroxide, lysozyme and bacteriocin-like inhi- 
biting substances (BLIS), biosurfactants (glycolipids, rhamnolipids, lipopeptides, polysaccharide-protein complexes, phospholipids, fatty acids and neutral lipids) (Dworkin et al., 2006; Varma et al., 2010, 2011; Dobson et al., 2012).

The efficacy of probiotic preparations containing lactobacilli is largely due to the activity of various antimicrobial agents, including biosurfactants (Velraeds et al., 1996), which introduce a powerful intervention into biofilm communities by changing the surface properties of bacterial cells, reduce their adhesion (Ahimou et al., 2000) and hinder the development of biofilms and intercellular interaction (Rasmussen and Givskov, 2006; Valle et al., 2006).

Consequently, the metabolites of lactobacilli are able to inhibit biofilm formation and cause ultrastructural changes in S. aureus and S. epidermidis cells, which leads to their death (Varma et al., 2011).

The aim of this study is to investigate the influence of lactobacilli on the ultrastructure of biofilm-forming clinical strains of staphylococci when co-cultured.

\section{Materials and methods}

For the investigation, 5 biofilm-forming clinical strains, isolated from the skin of acne vulgaris patients $(n=24)$, were selected. Primary selection of the strains was carried out on the basis of changes in their culture properties, including expressed increase in colony viscosity. Thus the proportion of biofilm-forming forms was $20.8 \%$. The strains of Lactobacillus fermentum $(\mathrm{n}=4)$ were isolated from the mucosa of the upper respiratory tract of healthy patients. Isolation and identification of staphylococci were performed using standard nutrient medium in the laboratory of the microbiology department of Danylo Halytskyi Lviv National Medical University according to the conventional techniques (Birger, 1982; Vos et al., 2009).

Staphylococcal biofilm formation was performed at the bottom of plastic cups (Ø $50 \mathrm{~mm}$ ) using nutrient broth ("Farmactiv", Ukraine), biofilm of lactobacilli - using MRS-broth (de Man, Rogosa, Sharpe, India). $4 \mathrm{ml}$ of broth and $10 \mu \mathrm{l}$ of culture with turbidity $1,5 \times 10^{9} \mathrm{CFU} / \mathrm{ml}$ (corresponding to $5 \mathrm{McFarland}$ units according to the standard) were added to each cup, in such a way that the suspension was uniformly distributed on the bottom of the cups. The cups with the staphylococci inoculations were placed in an incubator for 24 hours and the plates

\section{Table}

The dynamics of microorganisms growth after inoculation from biofilm

\begin{tabular}{|c|c|c|c|c|c|}
\hline \multirow{3}{*}{ Bacterial strains associants } & \multicolumn{5}{|c|}{ The number of microorganisms, CFU/ml } \\
\hline & \multirow{2}{*}{$\begin{array}{c}\text { inoculated } \\
\text { dose }\end{array}$} & \multirow{2}{*}{$0 \mathrm{~h}$} & \multicolumn{3}{|c|}{ the growth after inoculation from structured biofilm } \\
\hline & & & $12 \mathrm{~h}$ & $24 \mathrm{~h}$ & $48 \mathrm{~h}$ \\
\hline L. plantarum $8 \mathrm{P}-\mathrm{A} 3$ and & $10^{9}$ & $0^{*}$ & $(1.1 \pm 0.09) \times 10^{4}$ & $3 \times 10^{7}$ & $(0.9 \pm 0.08) \times 10^{12 *}$ \\
\hline S. aureus ATCC 25923 & $(1: 1)$ & $(4.7 \mathrm{x} \pm 0.02) \times 10^{8}$ & $(1.2 \pm 0.01) \times 10^{6}$ & $(1.35 \pm 0.09) \times 10^{2}$ & $0^{*}$ \\
\hline L. plantarum $8 \mathrm{P}-\mathrm{A} 3$ and & $10^{9}$ & $0 *$ & $(1.3 \pm 0.08) \times 10^{4}$ & $10^{8}$ & $(1.0 \pm 0.1) \times 10^{12}$ \\
\hline S. aureus ATCC 12228 & $(1: 1)$ & $(4.8 \mathrm{x} \pm 0.02) \times 10^{8}$ & $(2.0 \pm 0.02) \times 10^{6}$ & $75 \pm 0.56$ & $0 *$ \\
\hline L. fermentum, $\mathrm{N}=4$ & $10^{9}$ & $0 *$ & $(1.5 \pm 0.08) \times 10^{4}$ & $1.5 \times 10^{8}$ & $0.85 \pm 0.09) \times 10^{12 *}$ \\
\hline S. aureus (biofilm-forming form), $\mathrm{N}=5$ & $(1: 1)$ & $(4.6 \mathrm{x} \pm 0.02) \times 10^{8}$ & $(8.7 \pm 0.07) \times 10^{6}$ & $(1.35 \pm 0.09) \times 10^{2}$ & $(1.8 \pm 0.2) \times 10^{2} *$ \\
\hline L. fermentum, $\mathrm{N}=4$ & $10^{9}$ & $0^{*}$ & $3 \times 10^{4}$ & $1.5 \times 10^{7}$ & $(1.0 \pm 0.08) \times 10^{12 *}$ \\
\hline S. aureus ATCC 12228 & $(1: 1)$ & $(4.5 \mathrm{x} \pm 0.02) \times 10^{8}$ & $(1.2 \pm 0.04) \times 10^{6}$ & $(2.0 \pm 0.10) \times 10^{3}$ & $0 *$ \\
\hline
\end{tabular}

Note: statistically significant difference compared to control strains * $-\mathrm{P}<0.05$.

Growth of lactobacilli was absent. In isolation of cultures from structured biofilm samples association L. plantarum 8P-A3 as with the standard biofilm-forming strain of Staphylococcus and nonbiofilm form strain after 12 hours, the number of lactobacilli was $1.1 \pm 0.09 \times 10^{4}$ and $1.3 \pm 0.08 \times 10^{4} \mathrm{CFU} / \mathrm{ml}$, respectively, with an increase in the number of staphylococci to $(1.2 \pm 0.015)$ and $(2.0 \pm$ $0.03) \times 10^{6} \mathrm{CFU} / \mathrm{ml}$. After 24 hours, the number of viable staphylococci rapidly decreased to $(2.3 \pm 0.02)$ and $(2.0 \pm 0.04) \times 10^{3} \mathrm{CFU} / \mathrm{ml}$, and lactobacilli - increased to $10^{7-8} \mathrm{CFU} / \mathrm{ml}$.

The trend in the nature of isolation from biofilm structures of clinical isolates $L$. fermentum and $S$. aureus association was similar but more active isolation of both associant species was registered after 12 hours. After 24 hours the number of isolated L. fermentum was somewhat reduced in comparison with the activity of probiotic with the lactobacilli inoculations placed in an incubator for 48 hours, both at a temperature of $37^{\circ} \mathrm{C}$. After this exposure, the residual medium was collected from the cups in order not to destroy the existing biofilm and was washed with distilled water three times.

Similarly mixed cultures of Staphylococcus and Lactobacilli in MRS-broth were formed within 48 hours at $37^{\circ} \mathrm{C}$. For this $4 \mathrm{ml}$ of the mentioned medium and $5 \mu \mathrm{l}$ of lactobacilli and the staphylococcal suspension with density $1,5 \times 10^{9} \mathrm{CFU} / \mathrm{ml}$ were added to the plastic cups. As a control, a live culture of Lactobacillus plantarum 8P-A3, which is included in the composition of a probiotic preparation "Lactobacterin", which was obtained by cultivation in microaerophilic conditions first in thioglycollate medium and then on MRS-agar, was used. The standard film-forming strain of $S$. aureus 12228 , were used to determine a benchmark.

To determine the number of viable cells both the staphylococci and lactobacilli in mixed cultures of biofilms, inoculations of $10 \mu \mathrm{l}$ on the solid medium immediately after the inoculation and at 12 , 24, 48 hours were produced. In the case of a high density of the received culture it was diluted before the inoculation, which made it possible to set the number of germinated colonies.

Preparation of samples for transmission electron microscopy (TEM) was performed by classical methods (Weekly, 1975; Goldstein et al., 1984). They were viewed in the transmission electron microscope PEM-100-01 at a voltage of $75 \mathrm{kV}$ at magnifications from $\times 1,000$ to $\times 30,000$.

Statistical analysis of experimental data was performed using Excel for PC. The significance of the difference between the two rates was assessed by Student's test. The difference was considered significant at $\mathrm{P}<0.05$.

\section{Results and discussions}

Comparison of capacities for isolation from mixed cultures in a nutrient medium and in conditions of the biofilm structure modeling was conducted. Controlling inoculation on the solid medium immediately after the inoculation in all samples of mixed cultures has the inoculated dose from $(4.5 \pm 0.02)$ to $(4.8 \pm 0.04) \times 10^{8} \mathrm{CFU} / \mathrm{ml}$ (Table). ATCC 25923 and not the film-forming strain of S. aureus ATCC demonstrated the presence of staphylococci in an amount, close to

lactobacilli. Inhibition of Staphylococcus growth to $(1.35 \pm 0.09) \times 10^{2}$ (biofilm form) was also observed and this inhibition was even more pronounced with the non-biofilm forming standard strain of staphylococci $-75 \pm 0.56 \mathrm{CFU} / \mathrm{ml}$. In 48 hours after the inoculation on the medium lactobacilli, were isolated from all samples, and reached the quantitative level $10^{12}$. Isolation of staphylococcus was discontinued, except for L.fermentum and $S$. aureus (biofilm form, the number $\left.(1.8 \pm 0.2) \times 10^{2}\right)$ and the growth of individual colonies of clinical isolates of staphylococci in the modeling of biofilm was registered $(\mathrm{P}<0.05)$. Thus, clinical strains of lactobacilli adapted to the conditions of the organism are actively reproduced in vitro, being sufficiently effective antagonists under the conditions of biofilm. However, quantitatively, lactic acid lactobacilli promote more rapid death of staphylococci in a mixed culture. The studies also show higher 
potential of preservation of the viability of biofilm form bacteria in the bi-species biofilm. To assess the nature of the cell damage in the staphylococci in the mixed culture with the lactobacilli, the ulrastructure of these species of bacteria was studied in biofilm modeling conditions. In analyzing electron diffraction patterns in control samples of 24-hour film-forming monocultures and planktonic Staphylococcus and 48-hour lactobacilli, natural development of the population at the cellular level was observed (Fig. $1 a-c$ ). Cells were visualized at different stages of morphogenesis: separation with forming cytoplasmic wall, at rest, as well as with complete and partial autolysis (Fig. 1b).
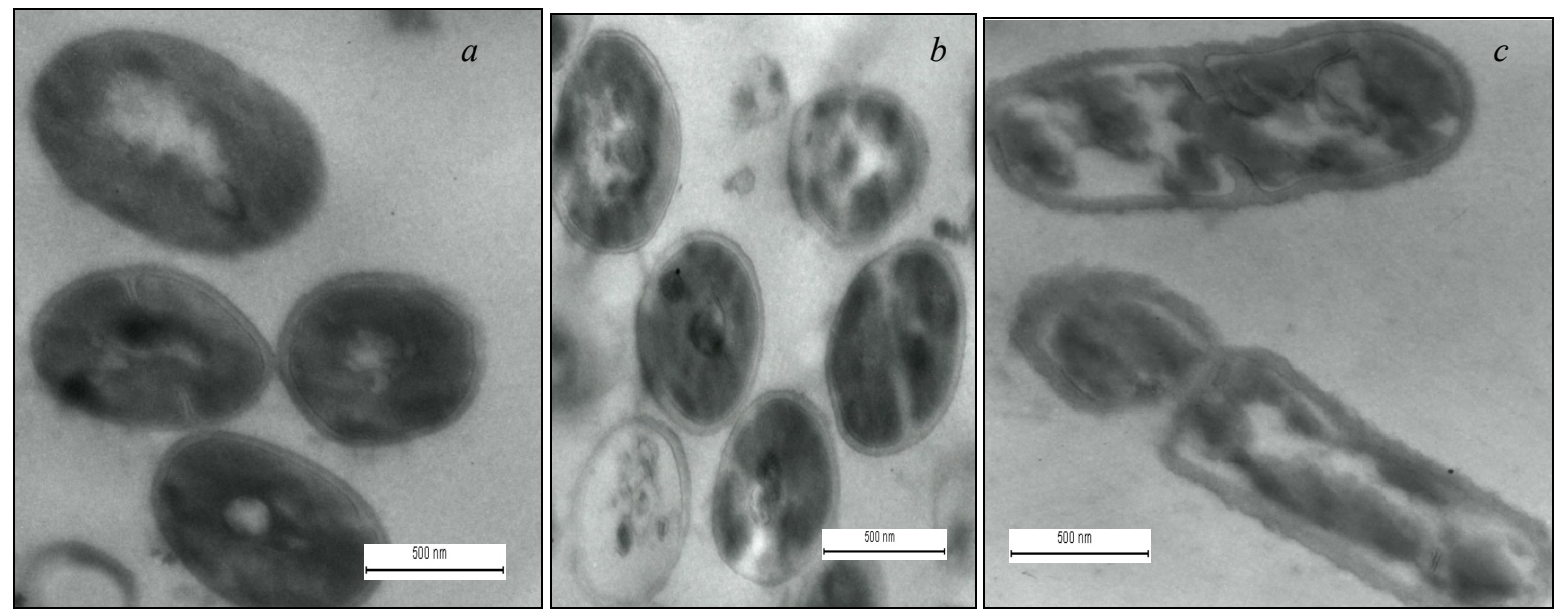

Fig. 1. Microphotography (TEM) of staphylococci and lactobacilli monocultures: (a) planktonic form of S. aureus ATCC 12228, (b) biofilm form of $S$. aureus ATCC 25923 at different stages of cell development, (c) clinical strain of $L$. fermentum

In most cells, a characteristic ultrastructural organization was observed: thick peptidoglycan layer, cytoplasmic membrane, nucleoid located diffusely in the form of light fibrillar-threadlike DNA structures, mesosomes (vesicular and lamellar membrane structures) in the place of septum formation. With almost all ultrathin sections of lactobacilli cells, the surface S-layer is visible. Only in the mixed culture of lactobacilli with staphylococci is it expressed on a significantly larger scale (Fig. $2 c$ ).

Comparing the electron diffraction patterns of 48-hour staphylococcal monocultures and cultures mixed with lactobacilli in the composition of biofilms, significant destructive changes in the ultrastructure of staphylococcal cells were observed (Fig. 2). Destabilization of the cell wall was manifested in its thickening, in the irregular form acquired by the cocci, detachment of the cytoplasmic membrane from the cell wall (Fig. $2 f$ ) and in the complete destruction of the peptidoglycan layer (Fig. $2 a, e$ ). Cell wall ruptures with the outflow of cell content were also recorded (Fig. $2 b, e$ ), which leads to a complete loss of colloid and corresponding protoplasmic structures and appearance of "shadow-cells" (Fig. 2d). Due to the high electron density of the cytoplasm in the nucleoid zone, it was impossible to oberve characteristic pronounced fibrillar-threadlike structures of DNA, in some electron diffraction patterns mesosomelike formations were poorly contrasted. Such destructive changes were detected in all the ultrathin sections of cells of biofilm-forming and planktonic staphylococci induced by probiotic (Fig. $2 g, h$ ) as well as clinical lactobacilli (Fig. $2 a-e$ ).

It is known that bacterial cells, growing in adverse conditions of a natural or artificial environment, such as the depletion of nutrients, oxygen, inadequate $\mathrm{pH}$, etc. can be transformed into uncultivated (VBNC - viable but non-culturable) forms with a slow metabolism, but preserving their viability. The uncultivated state is characterized by a number of molecular, structural and functional characteristics of the biofilm (Lleo et al., 2007; Stewart and Franklin, 2008; Oliver, 2010; Trevors, 2011).

VBNC forms are in transient dormancy condition and are orientated towards adaptation to stress and are associated with significant dwarfism of cells, as well as the inability to grow on nutrient media. Nevertheless, uncultivated cells that retain a certain degree of metabolic activity can be restored in cultivated states with the help of appropriate stimulation (Oliver, 2010; Trevors, 2011; Zandri et al, 2012).

Our studies have shown that in the case of a combination of a biofilm form of $S$. aureus and clinical strains of lactobacilli dormant staphylococci cells are found in the field of view (Fig. 2a). Difficulties in the treatment of many bacterial infections are associated with formation of biofilm by microorganisms in the patient, which plays an important role in clinical medicine (Chebotar et al., 2010; $\mathrm{Qu}$ et al., 2010). One way to improve the effectiveness of antimicrobial therapy of diseases caused by staphylococci, is the use of tools that contribute to the disintegration of the biofilm to the transition of the pathogen in planktonic form. Microorganisms-antagonists in composition of eubiotic preparations, particularly, lactobacilli may be used for this (Samot and Badet, 2013; Lee and Kim, 2014; Nair et al., 2014).

Different Lactobacillus species are part of the natural human body biosystems and participate in the formation of multispecies biofilms which contain two or more members within the association. It has been proved that $L$. reuteri, on the basis of which a large number of probiotics are created, can prevent reproduction of pathogenic bacteria and restore the natural biofilm of the urogenital tract in women (Whitchurch et al., 2002; Younes et al., 2012).

The bacterial cell wall and its associated proteins mediate the interaction between the environment and the cytoplasm of microbial cells. It acts as a structural barrier against the action of toxic chemicals, protects the cell from changing environmental conditions and plays an important role in infection and pathogenicity (Dmitriev et al., 2004). Changes in cell wall thickness take place under the influence of various factors. In particular, its thickening has been fixed among strains of antibiotic-resistant $S$. aureus in the presence of antibiotics (Cui et al., 2000; Cui et al., 2003; Kim et al., 2012). Increase in the thickness of the cell wall and its changes in biochemical composition have also been obtained under the influence of cold stress (Onyango et al., 2012). The phenomenon of "shadow cells" with the release of cellular material outside is described in the study of the damaging effect of silver on Pseudomonas aeruginosa using TEM. The results obtained are confirmed by the scanning electron microscopy (SEM): the complete loss of cell membranes with disintegration of intracellular material was recorded in the processed cells (Dosunmu et al., 2015). Similar investigations on the study of the silver ions mechanism of action were carried out on cultures of $S$. aureus and Escherichia coli. In gram-positive and gram-negative bacteria cell wall damage, the release of cell content, complete or partial separation of the cytoplasmic membrane from the cell wall, and decrease in electron density in the cytoplasm were identified (Jung et al., 2008). The interaction between the silver and the components of bacterial membrane 
causes structural changes and damage to membranes and intracellular metabolic activity, which may be the cause or the consequence of cell lysis (McDonnell et al., 1999; Sondi and Salopek-Sondi, 2004; Pal et al., 2007). Antiadhesive, antimicrobial and antibiofilm influence of biosurfactants produced by strains of $L$. jensenii and $L$. rhamnosus, in respect to a number of bacteria with clinical multidrug resistance (Acinetobacter baumannii, Escherichia coli and Staphylococcus aureus (MRSA)), which can form biofilms on wounds, medical implants and industrial surfaces was revealed.Confirmation of TEM has shown cell wall damage and the appearance of shadow-cells (Sambanthamoorthy et al., 2014).

Comparing our results with those of other researchers, it may be suggested that such reaction of the cell wall may be common to bacterial cells under the influence of different stress factors.
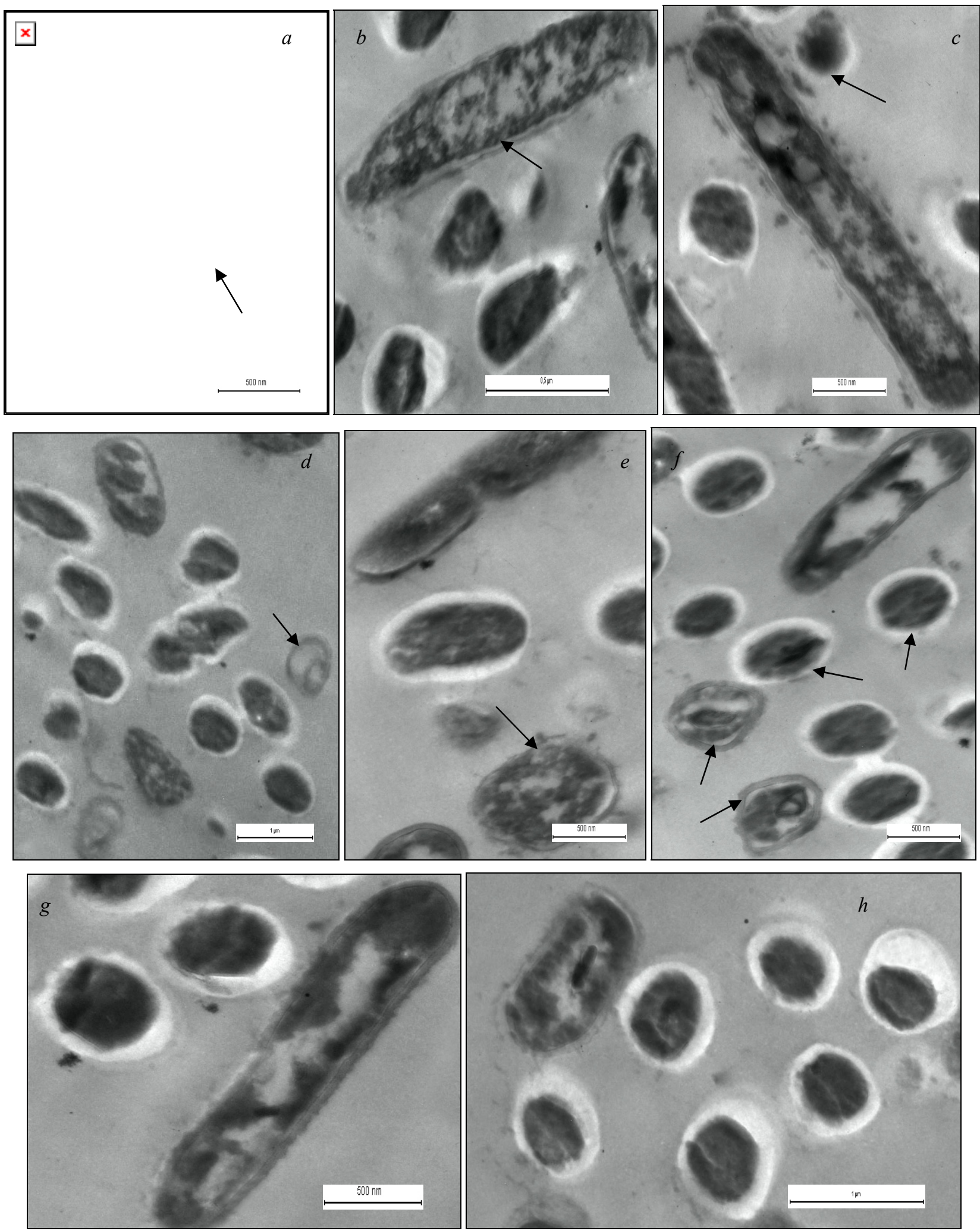

Fig 2. Microphotography (TEM) of mixed cultures of staphylococci and lactobacilli: (a) L. fermentum and S. aureus ATCC 12228 , (b) L. fermentum - excess of S-layer, $(c, d, e, f) L$. fermentum and biofilm form of $S$. aureus (ultrastructural changes in staphylococcal cells are marked with arrows), $(\mathrm{g})$ L. plantarum 8P-A3 and biofilm-forming form of S. aureus. L. plantarum 8P-A3 and S. aureus ATCC 12228 
In one recent study (Khaleghi and Kermanshahi, 2012), the authors showed that environmental conditions affect the protein of the S-layer and the slpA gene expression. During the electron-microscopic examination of Lactobacillus acidophilus ATCC 4356, the excess of the S-layer was found at both ends of the bacterial cell at a temperature of $45^{\circ} \mathrm{C}$. This allows one to suggest that the S-layer protein is predominantly expressed in conditions which are not optimal for bacterial growth. The S-layer probably acts as a protective shell in L. acidophilus ATCC 4356. In addition, the results of some studies indicate the involvement of lactobacilli S-layer proteins in providing hydrophobicity, autoaggregation and adhesion of these bacteria to a variety of surfaces (Van der Mei et al., 2003; Vadillo-Rodríguez et al., 2004; Khaleghi and Kermanshahi, 2012; Hynönen and Palva, 2013).

In our studies, when comparing the S-layer of lactobacilli in mono- and mixed cultures, its increase was seen only in the second case - in the mixed culture of lactobacilli with staphylococci. These results confirm the hypothesis that the observed changes are the indicators of the reaction general to the bacteria manifested by morphological modifications in the conditions of interaction with the "unfriendly" assiociants.

\section{Conclusions}

In terms of bi-species biofilm modeling, survival of assiociants of both species increases. The probiotic strain of lactobacilli reveals a more pronounced antagonistic effect on the staphylococci cultures in comparison with the activity of clinical isolates, while maintaining a minimum viability of probiotic forms of Staphylococcus. At the population level, the ratio of morphological types of $S$. aureus cells with an increase in the amount of involutional and lysed cells changed. Significant ultrastructural changes took place at the morphological level of staphylococcal cells. In mixed cultures of clinical strains of lactobacilli and biofilm-forming staphylococci, the latter moved into a state of rest, fixed by TEM, and during inoculation they retained their capacity for cultivation in vitro, which indicates the high competitiveness of staphylococci. Thanks to an experimental model of biofilm in a mixed culture, the present study has allowed us to establish the nature of the antagonistic action of lactobacilli on $S$. aureus and to evaluate the development of destructive changes in the dynamics. The results obtained can be used in improving the schemes of complex antimicrobial therapy of pyoinflammatory processes with the use of biological preparations, which are composed of lactobacilli, including those in the form of local application.

\section{References}

Ahimou, F., Jacques, P., \& Deleu, M. (2000). Surfactin and iturin A effects on Bacillus subtilis surface hydrophobicity. Enzyme and Microbial Technology, 27(10), 749-754.

Birger, M. I. (ed.) (1982). Spravochnik po mikrobiologicheskim i virusologicheskim metodam issledovanija [Handbook on microbiological and virological research methods]. Medicine, Moscow (in Russian).

Bondarenko, V. M. (2011). Rol' uslovno-patogennyh bakterij pri hronicheskih vospalitel'nyh processah razlichnoj lokalizacii [The role of opportunistic bacteria in chronic inflammatory processes of different localization]. Triada, Tver (in Russian).

Cameotra, S. S., Makkar, R. S., Kaur, J., \& Mehta, S. K. (2010). Synthesis of biosurfactants and their advantages to microorganisms and mankind in Biosurfactants. Springer, New York.

Chebotar, I. V., Mayansky, A. N., Konchakova, E. D., Lazareva, A. V., \& Chistyakova, V. P. (2012). Antibiotikorezistentnost' biopljonochnyh bakterij [Antimicrobial resistance of bacteria in biofilms]. Clinical Microbiology and Antimicrobial Chemotherapy, 14(1), 51-57 (in Russian).

Cui, L., Ma, X., Sato, K., Okuma, K., Tenover, F. C., Mamizuka, E. M., Gemmell, C. G., Kim, M. N., Ploy, M. C., El-Solh, N., Ferraz, V., \& Hiramatsu, K. (2003). Cell wall thickening is a common feature of vancomycin resistance in Staphylococcus aureus. Journal of Clinical Microbiology, 41(1), 5-14.

Cui, L., Murakami, H., Kuwahara-Arai, K., Hanaki, H., \& Hiramatsu, K. (2000). Contribution of a thickened cell-wall and its glutamine non-amidated component to the vancomycin resistance expressed by Staphylococcus aureus Mu50. Antimicrobial Agents Chemotherape, 44(9), 2276-2285.
Dall'Antonia, M., Coen, P. G., Wilks, M., Whiley, A., \& Millar, M. (2005) Competition between methicillin-sensitive and-resistant Staphylococcus aureus in the anterior nares. Journal of Hospital Infection, 61(1), 62-67.

Derkach, M. P., Humetsky, R. J., \& Chaban, M. E. (1977). Kurs variacijnoi' statystyky [A course of the variation statistics]. Vyshha Shkola, Kyiv (in Ukranian).

Dmitriev, B. A., Toukach, F. V., Holst, O., Rietschel, E. T., Ehlers, S. (2004) Tertiary structure of Staphylococcus aureus cell wall murein. Journal of Bacteriology, 186, 7141-7148.

Dobson, A., Cotter, P. D., Ross, R. P., \& Hill, C. (2012). Bacteriocin production: A probiotic trait? Applied and Environmental Microbiology, 78(1), 1-6.

Dosunmu, E., Chaudhari, A. A., Singh, S. R., Dennis, V. A., \& Pillai, S. R. (2015). Silver-coated carbon nanotubes downregulate the expression of Pseudomonas aeruginosa virulence genes: A potential mechanism for their antimicrobial effect. Journal of Clinical Microbiology, 10, 5025-5034.

Dworkin, M., Falkow, S., Rosenberg, E., Schleifer, K.-H., Stackebrandt, E. (2006). The prokaryotes: Vol. 4: Bacteria: Firmicutes, Cyanobacteria. Springer-Verlag, New York.

Eftekhar, F., \& Mirmohamadi, Z. (2009). Evaluation of biofilm production by Staphylococcus epidermidis isolates from nosocomial infections and skin of healthy volunteers. International Journal of Medicine and Medical Sciences, 1(10), 438-441.

Ghannoum, M., \& O'Toole, G. A. (2004). Microbial biofilms. ASM Press, Washington.

Goldstein, J., Newbury, D. E., Echlin, P., Joy, D. C., Fiori, C., Lifshin, E. (1984) Pastrovaja jelektronnaja mikroskopija i rentgenovskij mikroanaliz [Scanning electron microscopy and X-ray microanalysis]. Mir, Moscow (in Russian).

Gostev, V. V., \& Sidorenko, S. V. (2010). Bakterial'nye bioplenki i infekcii [Bacterial biofilms and infections]. Zhurnal Infektologii, 2(3), 4-15 (in Russian).

Hall-Stoodley, L., \& Stoodley, P. (2009). Evolving concepts in biofilm infections. Cell Microbiology, 11, 1034-1043.

Harriott, M. M., \& Noverr, M. C. (2009). Candida albicans and Staphylococcus aureus form polymicrobial biofilms: Effects on antimicrobial resistance. Antimicrobial Agents Chemotherape, 53, 3914-3922.

He, X., Hu, W., He, J., Guo, L., Lux, R., \& Shi, W. (2011). Community-based interference against integration of Pseudomonas aeruginosa into human salivary microbial biofilm. Molecular Oral Microbiology, 26(6), 337-352.

Hynönen, U., \& Palva, A. (2013). Lactobacillus surface layer proteins: Structure, function and applications. Applied Microbiology and Biotechnology, 97(12), 5225-5243.

Jung, W. K., Koo, H. C., Kim, K. W., Shin, S., Kim, S. H., \& Park, Y. H. (2008). Antibacterial activity and mechanism of action of the silver ion in Staphylococcus aureus and Escherichia coli. Applied and Environmental Microbiology, 74(7), 2171-2178.

Khaleghi, M., \& Kermanshahi, R. K. (2012). Effect of environmental stresses on S-layer production in Lactobacillus acidophilus ATCC 4356. Advances in Applied Microbiology, 3, 209-224.

Kim, J. W., Chung, G. T., Yoo, J. S., Lee, Y. S., \& Yoo, J. I. (2012). Autolytic activity and molecular characteristics of Staphylococcus haemolyticus strains with induced vancomycin resistance. Journal of Medical Microbiology, 61(10), 1428-1434.

Kluytmans, J., Van Belkum, A., \& Verbrugh, H. (1997). Nasal carriage of Staphylococcus aureus: Epidemiology, underlying mechanisms, and associated risks. Clinical Microbiology Reviews, 10(3), 505-520.

Lee, S. H., \& Kim, Y. J. (2014). A comparative study of the effect of probiotics on cariogenic biofilm model for preventing dental caries. Archives of Microbiology, 196(8), 601-609.

Lleo, M., Bonato, B., Tafi, M. C., Caburlotto, G., Benedetti, D., \& Canepari, P. (2007). Adhesion to medical device materials and biofilm formation capability of some species of enterococci in different physiological states. FEMS Microbiology Letters, 274(2), 232-237.

Macfarlane, S. (2008). Microbial biofilm communities in the gastrointestinal tract. Journal of Clinical Gastroenterology, 242(3), 142-143.

McDonnell, G., \& Russell, A. D. (1999). Antiseptics and disinfectants: Activity, action, and resistance. Clinical Microbiology Reviews, 12, 147-179.

Nair, N., Biswas, R., Götz, F., Biswas, L. (2014). Impact of Staphylococcus aureus on pathogenesis in polymicrobial infections. Infection and Immunity, 82(6), 2162-2169.

Oliver, J. D. (2010). Recent findings on the viable but nonculturable state in pathogenic bacteria. FEMS Microbiology Reviews, 34(4), 415-425.

Olson, M. E., Ceri, H., Morck, D. W., Buret, A. G., \& Read, R. R. (2002). Biofilm bacteria: Formation and comparative susceptibility to antibiotics. Canadian Journal of Veterinary Research, 66(2), 86-92.

Onyango, L. A, Dunstan, R. H, Gottfries, J., von Eiff, C., Roberts, T. K. (2012). Effect of low temperature on growth and ultrastructure of Staphylococcus spp. PLoS One, 7(1), e29031.

Otto, M. (2008). Staphylococcal biofilms. In: Bacterial biofilms. Springer, Berlin, Heidelberg. 
Pal, S., Tak, Y. K., Song, J. M. (2007). Does the antibacterial activity of silver nanoparticles depend on the shape of the nanoparticle? A study of the gram-negative bacterium Escherichia coli. Applied and Environmental Microbiology, 73(6), 1712-1720.

Pascual, A. (2002). Pathogenesis of catheter-related infections: Lessons for new designs. Clinical Microbiology and Infection, 8, 256-264.

Qu, Y., Daley, A. J., Istivan, T. S., Garland, S. M., \& Deighton, M. A. (2010) Antibiotic susceptibility of coagulase-negative staphylococci isolated from very low birth weight babies: Comprehensive comparisons of bacteria at different stages of biofilm formation. Annals of Clinical Microbiology and Antimicrobials, 9(1), 16.

Rasmussen, T. B., \& Givskov, M. (2006). Quorum-sensing inhibitors as antipathogenic drugs. International Journal of Medical Microbiology, 296(2), $149-161$.

Reid, G. (1999). Biofilms in infectious disease and on medical devices. International Journal of Antimicrobial Agents, 11(3), 223-226.

Revdiwala, S., Rajdev, B. M., \& Mulla, S. (2012). Characterization of bacterial etiologic agents of biofilm formation in medical devices in critical care setup. Critical Care Research and Practice, 2012, 945805.

Sambanthamoorthy, K., Feng, X., Patel, R., Patel, S., \& Paranavitana, C. (2014). Antimicrobial and antibiofilm potential of biosurfactants isolated from lactobacilli against multi-drug-resistant pathogens. BMC Microbiology, 14(1), 197.

Samot, J., \& Badet, C. (2013). Antibacterial activity of probiotic candidates for oral health. Anaerobe, 19, 34-38.

Shyrobokov, V., Jankowski, D., \& Dement, G. (2009). Mikrobna ekologija ljudyny z kol'orovym atlasom [Microbial ecology of the human with colored atlas]. Chervona Ruta, Kyiv (in Ukranian).

Sondi, I., \& Salopek-Sondi, B. (2004). Silver nanoparticles as antimicrobial agent: A case study on E. coli as a model for Gram-negative bacteria. Journal of Colloid and Interface Science, 275(1), 177-182.

Stewart, P. S., \& Franklin, M. J. (2008). Physiological heterogeneity in biofilms. Nature Reviews Microbiology, 6(3), 199-210.

Trevors, J. T. (2011). Viable but non-culturable (VBNC) bacteria: Gene expression in planktonic and biofilm cells. Journal of Microbiological Methods, 86(2), 266-273.

Vadillo-Rodríguez, V., Busscher, H. J., Norde, W., De Vries, J., \& Van Der Mei, H. C. (2004). Dynamic cell surface hydrophobicity of Lactobacillus strains with and without surface layer proteins. Journal of Bacteriology, 186(19), $6647-6650$.

Valle, J., Da Re, S., Henry, N., Fontaine, T., Balestrino, D., Latour-Lambert, P., \& Ghigo, J. M. (2006). Broad-spectrum biofilm inhibition by a secreted bacterial polysaccharide. Proceedings of the National Academy of Sciences, 103(33), 12558-12563.
Van der Mei, H. C., Van de Belt-Gritter, B., Pouwels, P. H., Martinez, B., \& Busscher, H. J. (2003). Cell surface hydrophobicity is conveyed by Slayer proteins - a study in recombinant lactobacilli. Colloids and Surfaces B: Biointerfaces, 28(2), 127-134.

Varma, P., Dinesh, K. R, Menon, K. K, Biswas, R. (2010). Lactobacillus fermentum isolated from human colonic mucosal biopsy inhibits the growth and adhesion of enteric and foodborne pathogens. Journal of Food Science, 75, M546-M551.

Varma, P., Nisha, N., Dinesh, K. R., Kumar, A. V., \& Biswas, R. (2011). Antiinfective properties of Lactobacillus fermentum against Staphylococcus aureus and Pseudomonas aeruginosa. Journal of Molecular Microbiology and Biotechnology, 20(3), 137-143.

Velraeds, M. M., Van der Mei, H. C., Reid, G., \& Busscher, H. J. (1996). Physicochemical and biochemical characterization of biosurfactants released by Lactobacillus strains. Colloids and Surfaces B: Biointerfaces, 8(1-2), 51-61.

Vos, P., Garrity, G., Jones, D., Krieg, N. R., Ludwig, W., Rainey, F. A., Schleifer, K.-H., \& Whitman, W. (eds.) (2009). Bergey's manual of systematic bacteriology: Vol. 3: The Firmicutes. Springer.

Wang, C.-Y., Wang, H.-C., Li, J.-M., Wang, J.-Y., Yang, K.-C., \& Ho, Y.-K. (2010). Invasive infections of Aggregatibacter (Actinobacillus) actinomycetemcomitans. Journal of Microbiology, Immunology and Infection, 43(6), 491-497.

Weekly, B. S. (1975). Jelektronnaja mikroskopija dlja nachinajushhih [Electron microscopy for beginners]. Mir, Moscow (in Russian).

Weinstein, R. A., \& Darouiche, R. O. (2001). Device-associated infections: A macroproblem that starts with microadherence. Clinical Infectious Diseases, 33(9), 1567-1572.

Wertheim, H. F., Melles, D. C., Vos, M. C., van Leeuwen, W., van Belkum, A., Verbrugh, H. A., \& Nouwen, J. L. (2005). The role of nasal carriage in Staphylococcus aureus infections. The Lancet Infectious Diseases, 5(12), 751-762.

Whitchurch, C. B., Tolker-Nielsen, T., Ragas, P. C., \& Mattick, J. S. (2002). Extracellular DNA required for bacterial biofilm formation. Science, 295(5559), 1487-1487.

Younes, J. A., van der Mei, H. C., van den Heuvel, E., Busscher, H. J., \& Reid, G. (2012). Adhesion forces and coaggregation between vaginal staphylococci and lactobacilli. PloS One, 7(5), e36917.

Zandri, G., Pasquaroli, S., Vignaroli, C., Talevi, S., Manso, E., Donelli, G., \& Biavasco, F. (2012). Detection of viable but non-culturable staphylococci in biofilms from central venous catheters negative on standard microbiological assays. Clinical Microbiology and Infection, 18(7), E259-E261. 